\title{
Mesenchymal Stem Cell Differentiation into Adipocytes Is Equally Induced by Insulin and Proinsulin In Vitro
}

\author{
Andreas Pfützner ${ }^{1,2}$, Dorothee Schipper ${ }^{3}$, Andreas Pansky ${ }^{3}$, \\ Claudia Kleinfeld ${ }^{3}$, Barbara Roitzheim ${ }^{3}$, Edda Tobiasch ${ }^{3}$ \\ ${ }^{1}$ Pfützner Science $\mathcal{E}$ Health Institute, Mainz, Germany, ${ }^{2}$ Technical University of Applied Sciences, Bingen, Germany \\ ${ }^{3}$ Bonn-Rhein-Sieg University of Applied Sciences, Rheinbach, Germany
}

Background and Objectives: In advanced $\beta$-cell dysfunction, proinsulin is increasingly replacing insulin as major component of the secretion product. It has been speculated that proinsulin has at least the same adipogenic potency than insulin, leading to an increased tendency of lipid tissue formation in patients with late stage $\beta$-cell dysfunction. Methods and Results: Mesenchymal stem cells obtained from liposuction material were grown in differentiation media containing insulin $(0.01 \mu \mathrm{mol})$, proinsulin $(0.01 \mu \mathrm{mol})$ or insulin + proinsulin (each $0.005 \mu \mathrm{mol})$. Cell culture supernatants were taken from these experiments and an untreated control at weeks 1,2 , and 3 , and were stored at $-80^{\circ} \mathrm{C}$ until analysis. Cell differentiation was microscopically supervised and adiponectin concentrations were measured as marker for differentiation into mature lipid cells. This experiment was repeated three times. No growth of lipid cells and no change in adiponectin values was observed in the negative control group (after 7/14/12 days: $3.2 \pm 0.5 /$ $3.3 \pm 0.1 / 4.4 \pm 0.5 \mathrm{ng} / \mathrm{ml} / 12 \mathrm{~h}$ ). A continuous differentiation into mature adipocytes (also confirmed by Red-Oil-staining) and a corresponding increase in adiponectin values was observed in the experiments with insulin $(3.6 \pm 1.9 / 5.1 \pm 1.4 /$ $13.3 \pm 1.5 \mathrm{ng} / \mathrm{ml} / 12 \mathrm{~h} ; \mathrm{p}<0.05$ week 1 vs. week 3$)$ and proinsulin $(3.3 \pm 1.2 / 3.5 \pm 0.3 / 12.2 \pm 1.2 \mathrm{ng} / \mathrm{ml} / 12 \mathrm{~h} ; \mathrm{p}<0.05)$. Comparable effects were seen with the insulin/proinsulin combination.

Conclusions: Proinsulin has the same adipogenic potential than insulin in vitro. Proinsulin has only $10 \sim 20 \%$ of the glucose-lowering effect of insulin. It can be speculated that the adipogenic potential of proinsulin may be a large contributor to the increased body weight problems in patients with type 2 diabetes and advanced $\beta$-cell dysfunction.

Keywords: Intact proinsulin, $\beta$-cell dysfunction, Visceral lipid tissue, Adipogenic effect, Stem cell differentiation

\section{Introduction}

The pathogenetic development of type 2 diabetes is

Accepted for publication September 14, 2017, Published online November 30, 2017

Correspondence to Andreas Pfützner

Pfützner Science \& Health Institute, Parcusstr. 8, D-55116 Mainz, Germany

Tel: +49-6131-5884640, Fax: +49-6131-5884644

E-mail: Andreas.pfuetzner@pfuetzner-mainz.com

(c) This is an open-access article distributed under the terms of the Creative Commons Attribution Non-Commercial License (http://creativecommons.org/ licenses/by-nc/4.0/), which permits unrestricted non-commercial use, distribution, and reproduction in any medium, provided the original work is properly cited.

Copyright (c) 2017 by the Korean Society for Stem Cells Research characterized by a hereditary $\beta$-cell dysfunction, associated with a major hormonal activity of the visceral lipid tissue and a resulting chronic systemic inflammation and insulin resistance, which in turn increases the demand for insulin from the $\beta$-cells $(1,2)$. During a year-long development of the disease, there is a progredient decrease in $\beta$-cell cleavage and processing capacity, and as consequence immature precursor proteins including uncleaved intact proinsulin are secreted, which can be used for differential diagnosis and to describe the stage of $\beta$ -cell dysfunction and insulin resistance in the individual patient $(3,4)$. In the attempt to keep and maintain a normal blood glucose control while patients gain weight and experience an increasing insulin resistance, the $\beta$-cells are forced to secrete consistently higher amounts of their secre- 
tion product. From past clinical trials with s.c. administration of intact proinsulin, it has become evident that proinsulin has only $10 \sim 20 \%$ of the glucose lowering effect of insulin $(5,6)$. The requirement to produce and secrete more of this less effective protein may be one of the key contributors to a final complete $\beta$-cell exhaustion, which clinically leads to insulin-dependency of the patient.

Insulin is the only hormone known to date that is capable to induce differentiation and growth of lipid tissue. Untreated, the absolute lack of insulin in type 1 diabetes results in major weight loss, cachexia and diabetic ketoacidosis, while the same is usually not observed in patients with a relative lack of insulin during the later development of type 2 diabetes (7). In contrary, it is well known that patient have a major tendency to gain further weight. Diet and exercise have become key pillars of an effective treatment of diabetes mellitus since decades (7-9). It is tempting to speculate that the increasing amounts of proinsulin, while having only a modest blood glucose-lowering effect, might at the same time drive differentiation of mesenchymal stem cells to become pre-adipocytes with the same lipogenic activity as completely processed insulin.

Human mesenchymal stem cells (hMSCs) isolated from liposuction material have been described as a convenient model for the study of human adipogenesis, including the early stages of the differentiation process (10). By employing a standardized protocol for isolation and purification of human mesenchymal stem cells derived from liposuction material with a consecutive attempt to induce differentiation through appropriate media, we investigated the potential impact of proinsulin to drive differentiation of stem cells into pre-adipocytes, and compared it to the in-vitro effect of insulin under the same laboratory conditions.

\section{Materials and Methods}

This work was performed in accordance with applicable ethical standards and German legal regulations, and the responsible ethical review committee approved the use of the liposuction material for this laboratory study.

\section{Isolation and differentiation of adipose tissue-derived mesenchymal stem cells}

Human adipose tissue-derived mesenchymal stem cells were obtained from raw human lipoaspirates from two donors (a 53 yr. old female subject and a 64 yr. old male subject, both non-diabetic) and cultured as previously described by Zuk et al. (11) and Zhu et al. (12). The hMSCs were isolated by their ability of adherence to the culture flask. The first medium change removed the non-adherent cells after three days. Briefly, raw liposuction material with diluted with $1 \mathrm{x}$ sterile phosphate-buffered saline (PBS) in a ratio of 1:2 at room temperature for 30 minutes in order to obtain a separation into a lower blood and an upper fat phase followed by centrifugation at $200 \times \mathrm{g}$ for 10 minutes at room temperature. The pellets were washed with $1 \times$ PBS. Remaining red blood cells were destroyed by incubation with erythrolysis buffer $\left(1 \times 10^{-4} \mathrm{M}\right.$ EDTA [pH 8.0], $0.154 \mathrm{M} \mathrm{NH}_{4} \mathrm{Cl}, 1 \times 10^{-2} \mathrm{M} \mathrm{KHCO}_{3}$ ) for $10 \mathrm{mi}-$ nutes at room temperature. The upper phase was treated with $0.075 \%$ collagenase (type I; Sigma-Aldrich, St. Louis, $\mathrm{MO}$ ) in PBS for $30 \mathrm{~min}$ at $37^{\circ} \mathrm{C}$ with gentle agitation. The collagenase was inactivated with an equal volume of DMEM/10\% fetal bovine serum (FBS) and the infranatant centrifuged for $10 \mathrm{~min}$ at $200 \times \mathrm{g}$. The cellular pellet was re-suspended in DMEM/10\% FBS and filtered through a $100 \mu \mathrm{m}$ mesh filter to remove debris. The filtrate was centrifuged as detailed above and plated onto conventional tissue culture plates in control medium (500 ml DMEM [4.5 g/L glucose, with L-glutamine], $50 \mathrm{ml}$ fetal bovine serum [heat inactivated], $5 \mathrm{ml}$ penicillin/streptomycin, [10,000 IU penicillin, $10,000 \mu \mathrm{g} / \mathrm{ml}$ streptomycin], $5 \mathrm{ml}$ amphotericin B [250 $\mu \mathrm{g} / \mathrm{ml}$ amphotericin B], sterile filtered and incubated at $37^{\circ} \mathrm{C}$ for $30 \mathrm{~min}$ prior to use).

The mesenchymal stem cells were induced with differentiation media (control medium with addition of dexamethasone [1.0 $\mu \mathrm{m}$ final], 3-isobutyl-1-methylxanthine [IBMX $0.5 \mathrm{~mm}$ final], indomethacin [0.2 $\mathrm{mm}$ final] and insulin [10.0 $\mu \mathrm{m}$ final], intact proinsulin, or the combination of both [5 $\mu \mathrm{mol}$ final each]). The same medium without addition of insulin or proinsulin served for the negative control experiments. The cells were incubated at $37^{\circ} \mathrm{C}$ with twice-daily renewal of the medium and cell culture supernatants were taken from these experiments and an untreated control after 8 days, 17 days, and 23 days, respectively. They were stored at $-80^{\circ} \mathrm{C}$ until analysis. Cell differentiation to the adipogenic lineage was microscopically supervised and confirmed by Oil Red O staining and determination of adiponectin in the supernatant. All experiments were carried out in triplicate and with cells derived from each donor.

\section{Oil Red 0 Staining}

Media was removed, and cells were fixed for $60 \mathrm{~min}$ using a $10 \%$ formal calcium fixative $\left(1.0 \mathrm{~g}\right.$ of $\mathrm{CaCl}_{2}, 25.0$

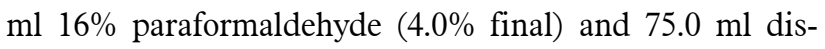
tilled water, all Sigma Aldrich). Thereafter, cells were washed two times with PBS, followed by another washing 
step with $70 \%$ ethanol, and 5 min incubation at room temperature with Oil Red O solution (2.0 g Oil Red O powder in $50.0 \mathrm{ml} \mathrm{70 \%} \mathrm{ethanol} \mathrm{and} 50.0 \mathrm{ml}$ acetone, all SIGMA Aldrich). Cells were washed with $70 \%$ ethanol and tap water and visually analyzed within $10 \sim 15 \mathrm{~min}$. A semiquantitative rank scale was used for this analysis $(0=$ no staining, $1=$ few individual cells with visible lipid granules, $2=$ less than $50 \%$ of visible cells with lipid granules, $3=$ majority of the visible cells have lipid granules).

\section{Measurement of total adiponectin in the supernatant}

Adiponectin concentrations were measured in the supernatant after 8 days, 17 days, and 23 days of incubation with daily renewal of the differentiation medium as protein secretion marker for differentiation into mature lipid cells by means of a sensitive radioimmunoassay (Adiponectin RIA, Linco, St. Charles, MO). The measurements were performed in triplicate with $100 \mu 1$ of supernatant taken 12 $\mathrm{h}$ after the last renewal of the differentiation medium.

\section{Statistical analysis}

The adiponectin results are presented as mean \pm STD and data were analysed by methods of descriptive statistics and interpreted in exploratory sense. Appropriate parametric and non-parametric methods were applied for comparison between day 7 and day 23. p-values $<0.05$ were considered statistically significant.

\section{Results}

All experiments were carried out as planned and without deviation from the protocol. Viable cells in an amount of $11.3 \times 10^{5}$ out of $13.0 \times 10^{5}$ were determined $(87 \%$ viably). The microscopy surveillance of the cell morphology revealed that no growth of lipid cells occurred in the control experiment. Also no secretion of adiponectin was ob-
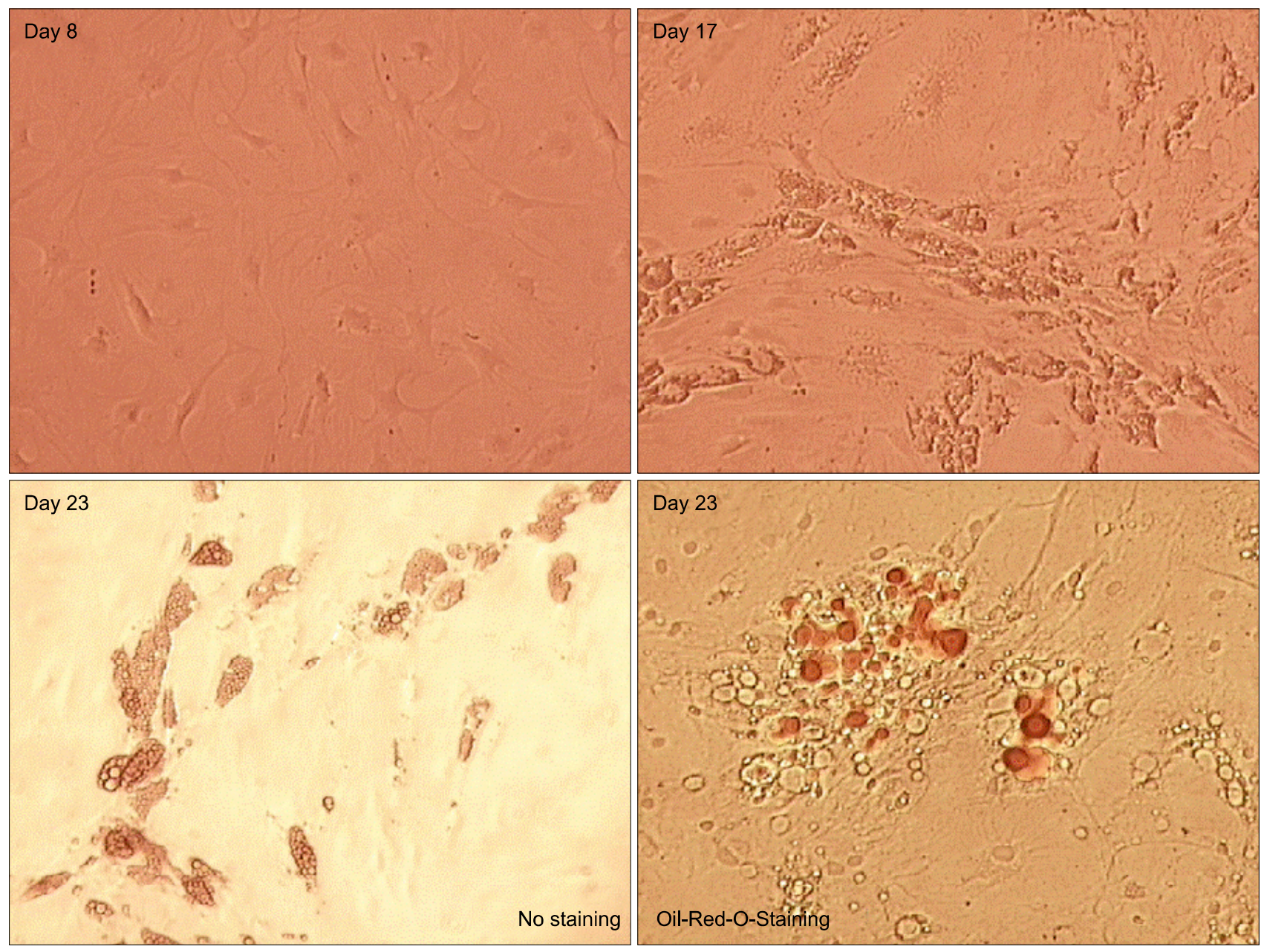

Fig. 1. Differentiation of adipose-tissue derived mesenchymal stem cells into adipocytes as seen microscopically and confirmed by Oil-Red-Staining 
served in the negative control experiments or could be seen at any of the the test days (adiponectin concentrations on day $8: 3.2 \pm 0.5 \mathrm{ng} / \mathrm{ml}$, day $17: 3.3 \pm 0.1 \mathrm{ng} / \mathrm{ml}$, and day 23: $4.4 \pm 0.5 \mathrm{ng} / \mathrm{ml}$ ).

The experiments conducted with addition of insulin or proinsulin resulted in differentiation of the cells into (pre-)adipocytes as proved by Oil Red O staining. Fig. 1 shows a typical example of the microscopic appearance of the cells when induced by insulin at the different analysis days of the experiment. As can be seen, a continuous differentiation towards mature adipocytes was observed, which was confirmed by a corresponding increase in adiponectin values at the end of the experiment at day 23 . With the standard insulin-containing differentiation medium adiponectin levels were $3.6 \pm 1.9 \mathrm{ng} / \mathrm{ml}$ on day 8 , $5.1 \pm 1.4 \mathrm{ng} / \mathrm{ml}$ on day 17 , and $13.3 \pm 1.5 \mathrm{ng} / \mathrm{ml}$ on day 23 $(\mathrm{p}<0.05$ vs. day 8 and day 17).

A comparable differentiation pattern was seen when insulin was replaced with an equimolar amount of proinsulin (day 8: $3.3 \pm 1.2 \mathrm{ng} / \mathrm{ml}$, day 17: $3.5 \pm 0.3 \mathrm{ng} / \mathrm{ml}$, and day 23: $12.2 \pm 1.2 \mathrm{ng} / \mathrm{ml} ; \mathrm{p}<0.05$ vs. day 8 and 17 ) or with the equimolar 50:50 mixture of insulin and proinsulin (day 8: $3.5 \pm 0.7 \mathrm{ng} / \mathrm{ml}$, day $17: 4.0 \pm 0.2 \mathrm{ng} / \mathrm{ml}$, and day 23 : $14.6 \pm 3.0 \mathrm{ng} / \mathrm{ml} ; \mathrm{p}<0.05$ vs. day 8 and 17$)$. The comparison of these results with the results derived from the control experiment are shown in Fig 2.

All differentiation experiments with media containing insulin and/or proinsulin resulted in similar numbers of differentiated cells as confirmed by cell count and Oil Red O staining ( $\sim 1,500$ cells $/ \mathrm{cm}^{2}$ with stained lipid granules), with a typical ranking of " 3 " in all cases on day 23 (see Fig. 1). In previous experiments, we have shown the reli-

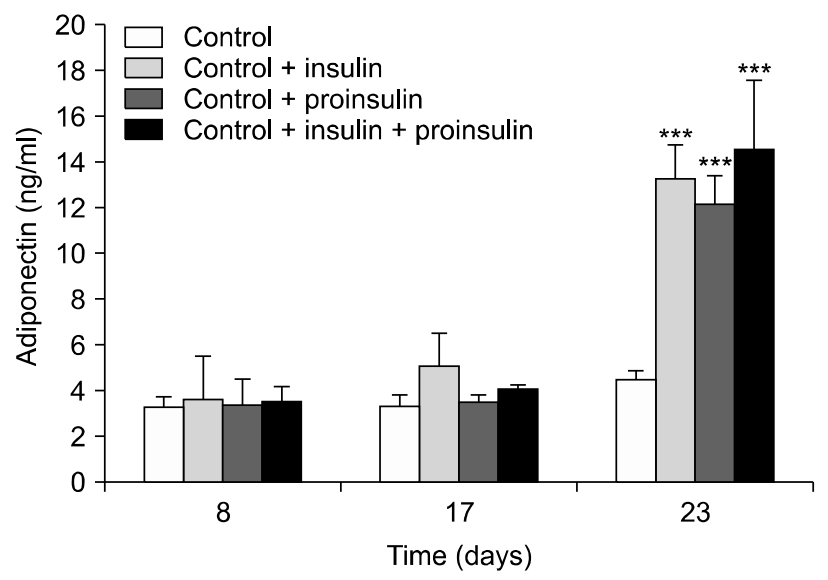

Fig. 2. The adiponectin secretion from differentiating mesenchymal stem cells cultivated with insulin and proinsulin in vitro confirms that the lipogenic effect of proinsulin is equipotent to the lipogenic action of insulin. ${ }^{* * *} \mathrm{p}<0.001$. ability of this protocol to result in adipocyte differentiation also with other biomarkers not tested here (termination of the differentiation process usually occurs at around day 20) (13).

\section{Discussion}

In this study, we used human adipose tissue derived mesenchymal stem cells and their differentiation pattern as an in vitro model for obesity-associated cell differentiation to identify the lipogenic potential of proinsulin in comparison to insulin. We assessed morphological changes and Oil Red O staining and measured adiponectin secretion into the supernatant as indication for the differentiation of the stem cells towards mature adipocytes. Our adiponectin concentrations measured after three weeks of cultivation with normal insulin-containing adipogenic differentiation medium $(\sim 12 \mathrm{ng} / \mathrm{ml} / 12 \mathrm{~h})$ were in line with previously published results regarding the secretion of adiponectin by mature adipocytes in vitro $(14,15)$. A similar adiponectin secretion was observed when adding proinsulin or a 50/50 insulin/proinsulin mixture in equimolar concentrations instead of insulin to the differentiation medium, while no differentiation to adipocytes occurred without addition of insulin or proinsulin.

As of today, insulin has been considered the only physiological hormone in the human body that is capable to built-up visceral and subcutaneous lipid tissue (16). Alternatively, the influence of pharmaceutical drugs (dexamethason and rosiglitazone) may also drive stem cell differentiation into the adipogenic lineage in a laboratory setting (17). Because of the established minor but notable glucose-lowering effect of unprocessed proinsulin, we speculated that proinsulin may also have some impact on lipid tissue generation. By using an established in-vitro model of adipose tissue differentiation with mesenchymal stem cells derived from liposuction material, we confirmed a lipogenic action of proinsulin in vitro, which was equal to the effect observed with regular human insulin.

Our study has several limitations, which need to be considered before interpreting the relevance of our findings for clinical practice. First, the experiment was a pilot experiment and only performed with mesenchymal stem cells derived from two donors. It will be important to confirm our findings with stem cells derived from multiple donors to exclude that they are only valid for individual subgroups. Second, we repeated the experiment only three times to be able to perform at least descriptive statistics. However, the observed effects between weeks two and three of our experiments were so pronounced and homoge- 
neous that we do not believe that a larger number of measurements would have change the outcome. Third and final, translation and interpretation of in-vitro results for clinical practice recommendations should only be performed with uppermost caution and only if other indications vote for justification of such an approach.

However, even with all limitations mentioned above, our results might explain several well-known findings in patients with type 2 diabetes and prediabetes:

During the development of type 2 diabetes, increased concentrations of fasting and postprandial intact proinsulin levels can occur as consequence of late stage $\beta$-cell dysfunction (stage III) $(3,4)$. Intact proinsulin has a moderate but notable glucose lowering effect, which may even mask or delay the glucose-based diagnosis of the disease $(5,6)$. Proinsulin lowers glucose only with $10 \%$ to $20 \%$ of the efficacy of insulin itself, when injected subcutanelously. So five proinsulin molecules are required to replace the action of one insulin molecule (6). As a logical consequence, determination of postprandial proinsulin in non-diabetic subjects was found to predict the development of glucose-defined type 2 diabetes or macrovascular events up to five years in advance in a pilot study (18). In addition, this diagnostic value of intact proinsulin when determined in fasting or postprandial blood samples for prediction of diabetes (19-22) but also of macrovascular events (23-25) has been confirmed in numerous well-documented prospective long-term epidemiological studies in small and large patient populations during the last decades.

This $\beta$-cell dysfunction-defined "prediabetes" stage is not characterized by glucose abnormalities, but by normal glucose levels and by elevated proinsulin levels as the only indicative parameter. As mentioned above, the blood glucose lowering potency of proinsulin is much lower than that of insulin and five to ten times more proinsulin needs to be secreted to control blood glucose in vivo. In consequence, there is an increased tendency for adipocyte differentiation. The enhanced number of differentiated pre-adipocytes results in an increased hormonal activity of the visceral adipose tissue with secretion of proinflammatory hormones and cytokines (26), which consecutively decrease plasma adiponectin levels and increase chronic systemic inflammation and insulin resistance (4, 27-29).

A main feature of this condition is insulin and leptin resistance as well as the production of inflammatory cytokines: TNF and IL 6 and monocyte chemoattractant protein. It has been shown that about $30 \%$ of circulating IL 6 comes from adipose tissue (30). IL- 6 causes insulin resistance by decreasing the expression of insulin re-

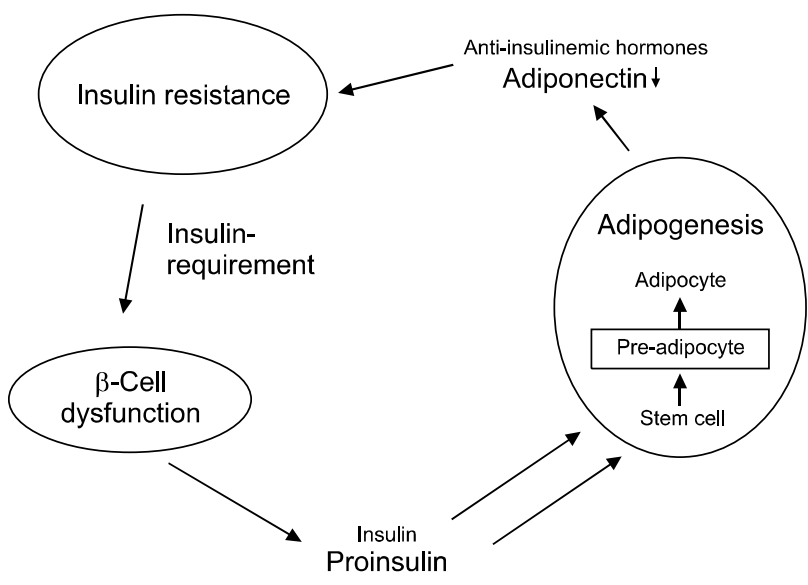

Fig. 3. Schematic presentation of the contribution of proinsulin to the overall impairment of the metabolic situation in case of severe $\beta$-cell dysfunction.

ceptors, decreases adipogenesis and adiponectin, and stimulates hepatic gluconeogenesis $(26,30)$. This means that excess of visceral adipose tissue results in the development of a chronic systemic inflammatory condition, which favors the development of insulin resistance and Type 2 diabetes.

Insulin resistance increases the pressure on the $\beta$-cells to produce more secretion product for glucose control (for a schematic representation see Fig. 3). Still patients will only gain weight with a positive caloric balance, i.e. if they eat more than what they metabolically burn. In any case, it can be speculated that the adipogenic potential of proinsulin may be a large contributor to the increased body weight problems, the observed chronic systemic inflammation (31) and associated risks in patients with type 2 diabetes and advanced $\beta$-cell dysfunction.

In conclusion, our pilot study has shown that proinsulin has a similar potential like insulin to drive mesenchymal stem cells into the adipogenic lineage. While this finding has to be confirmed in further studies, it may be indicative for an important role of proinsulin in the pathophysiology of weight gain, chronic systemic inflammation, and macrovascular disease in patients with type 2 diabetes mellitus.

\section{Potential conflict of interest}

The authors have no conflicting financial interest.

\section{References}

1. Wellen KE, Hotamisligil GS. Inflammation, stress, and diabetes. J Clin Invest 2005;115:1111-1119

2. Pfützner A, Weber MM, Forst T. A biomarker concept for 
assessment of insulin resistance, beta-cell function and chronic systemic inflammation in type 2 diabetes mellitus. Clin Lab 2008;54:485-490

3. Pfützner A, Kunt T, Hohberg C, Mondok A, Pahler S, Konrad T, Lübben G, Forst T. Fasting intact proinsulin is a highly specific predictor of insulin resistance in type 2 diabetes. Diabetes Care 2004;27:682-687

4. Pfützner A, Pfützner AH, Larbig M, Forst T. Role of intact proinsulin in diagnosis and treatment of type 2 diabetes mellitus. Diabetes Technol Ther 2004;6:405-412

5. Glauber HS, Henry RR, Wallace P, Frank BH, Galloway JA, Cohen RM, Olefsky JM. The effects of biosynthetic human proinsulin on carbohydrate metabolism in non-insulin-dependent diabetes mellitus. N Engl J Med 1987; 316:443-449

6. Galloway JA, Hooper SA, Spradlin CT, Howey DC, Frank $\mathrm{BH}$, Bowsher RR, Anderson JH. Biosynthetic human proinsulin. Review of chemistry, in vitro and in vivo receptor binding, animal and human pharmacology studies, and clinical trial experience. Diabetes Care 1992;15:666-692

7. American Diabetes Association. Standards in diabetes care 2017. Diabetes Care 2017;40(Suppl 1):S1-S135

8. Ivy JL. Role of exercise training in the prevention and treatment of insulin resistance and non-insulin-dependent diabetes mellitus. Sports Med 1997;24:321-336

9. Wallberg-Henriksson H, Rincon J, Zierath JR. Exercise in the management of non-insulin-dependent diabetes mellitus. Sports Med 1998;25:25-35

10. Janderová L, McNeil M, Murrell AN, Mynatt RL, Smith SR. Human mesenchymal stem cells as an in vitro model for human adipogenesis. Obes Res 2003;11:65-74

11. Zuk PA, Zhu M, Mizuno H, Huang J, Futrell JW, Katz AJ, Benhaim P, Lorenz HP, Hedrick MH. Multilineage cells from human adipose tissue: implications for cell-based therapies. Tissue Eng 2001;7:211-228

12. Zhu M, Heydarkhan-Hagvall S, Hedrick M, Benhaim P, Zuk P. Manual isolation of adipose-derived stem cells from human lipoaspirates. J Vis Exp 2013;(79):e50585

13. Pansky A, Roitzheim B, Tobiasch E. Differentiation potential of adult human mesenchymal stem cells. Clin Lab 2007;53:81-84

14. Nagahara K, Dobashi K, Ishikawa T, Nakano Y, Abe Y, Tanaka D, Itabashi K. AICAR attenuates TNF $\alpha$-induced inappropriate secretion of monocyte chemoattractant protein-1 and adiponectin in 3T3-L1 adipocytes. J Atheroscler Thromb 2016;23:1345-1354

15. Huypens P, Quartier E, Pipeleers D, Van de Casteele M. Metformin reduces adiponectin protein expression and release in 3T3-L1 adipocytes involving activation of AMP activated protein kinase. Eur J Pharmacol 2005;518:90-95

16. Pittenger MF, Mackay AM, Beck SC, Jaiswal RK, Douglas R, Mosca JD, Moorman MA, Simonetti DW, Craig S, Marshak DR. Multilineage potential of adult human mesenchymal stem cells. Science 1999;284:143-147

17. Contador D, Ezquer F, Espinosa M, Arango-Rodriguez M, Puebla C, Sobrevia L, Conget P. Dexamethasone and rosi- glitazone are sufficient and necessary for producing functional adipocytes from mesenchymal stem cells. Exp Biol Med (Maywood) 2015;240:1235-1246

18. Pfützner A, Hermanns I, Ramljak S, Demircik F, Pfützner $\mathrm{AH}$, Kann PH, Weber MM. Elevated intact proinsulin levels during an oral glucose challenge indicate progressive B-cell dysfunction and may be predictive for development of type 2 diabetes. J Diabetes Sci Technol 2015;9:1307-1312

19. Vangipurapu J, Stančáková A, Kuulasmaa T, Kuusisto J, Laakso $M$. Both fasting and glucose-stimulated proinsulin levels predict hyperglycemia and incident type 2 diabetes: a population-based study of 9,396 Finnish men. PLoS One 2015;10:e0124028

20. Zethelius B, Byberg L, Hales CN, Lithell H, Berne C. Proinsulin and acute insulin response independently predict Type 2 diabetes mellitus in men--report from 27 years of follow-up study. Diabetologia 2003;46:20-26

21. Nijpels G, Popp-Snijders C, Kostense PJ, Bouter LM, Heine RJ. Fasting proinsulin and 2-h post-load glucose levels predict the conversion to NIDDM in subjects with impaired glucose tolerance: the Hoorn Study. Diabetologia 1996;39:113-118

22. Kahn SE, Leonetti DL, Prigeon RL, Boyko EJ, Bergstrom RW, Fujimoto WY. Proinsulin as a marker for the development of NIDDM in Japanese-American men. Diabetes 1995;44:173-179

23. Zethelius B, Byberg L, Hales CN, Lithell H, Berne C. Proinsulin is an independent predictor of coronary heart disease: Report from a 27-year follow-up study. Circulation 2002;105:2153-2158

24. Lindahl B, Dinesen B, Eliasson M, Røder M, Hallmans G, Stegmayr B. High proinsulin levels precede first-ever stroke in a nondiabetic population. Stroke 2000;31:2936-2941

25. Lindahl B, Dinesen B, Eliasson M, Røder M, Jansson JH, Huhtasaari F, Hallmans G. High proinsulin concentration precedes acute myocardial infarction in a nondiabetic population. Metabolism 1999;48:1197-1202

26. Kuryszko J, Sławuta P, Sapikowski G. Secretory function of adipose tissue. Pol J Vet Sci 2016;19:441-446

27. Nordt TK, Bode C, Sobel BE. Stimulation in vivo of expression of intra-abdominal adipose tissue plasminogen activator inhibitor Type I by proinsulin. Diabetologia 2001;44:1121-1124

28. Frühbeck G. Overview of adipose tissue and its role in obesity and metabolic disorders. Methods Mol Biol 2008; 456:1-22

29. Schöndorf T, Maiworm A, Emmison N, Forst T, Pfützner A. Biological background and role of adiponectin as marker for insulin resistance and cardiovascular risk. Clin Lab 2005;51:489-494

30. Galic S, Oakhill JS, Steinberg GR. Adipose tissue as an endocrine organ. Mol Cell Endocrinol 2010;316:129-139

31. Ghanim H, Aljada A, Hofmeyer D, Syed T, Mohanty P, Dandona P. Circulating mononuclear cells in the obese are in a proinflammatory state. Circulation 2004;110:1564-1571 